\title{
Analysis and Development of the Mechanism of Investment Potential of the Tourist Network in a Pandemic
}

\author{
O. T. Ergunova ${ }^{1}$, Almaza Luis Molina ${ }^{2}$, P. V. Bochkov ${ }^{1}$, E. A. Blinova ${ }^{1, *}$ \\ ${ }^{1}$ Ural State University of Economics, Yekaterinburg, Russia \\ ${ }^{2}$ Vice-Rector for International Relations, S. Bolivar State Technological University (Republic of Peru) \\ *Corresponding author. Email: yekaterina-blinova-00@bk.ru
}

\begin{abstract}
Transformation of the mechanism for increasing the investment potential of the territories of Russia in the context of the COVID-2019 pandemic repeatedly strengthens the importance of an active policy in the field of forming the concept of promoting territories in general and in particular in the interregional market of tourist services. In the current conditions of the pandemic, fundamentally new goals and objectives of regional policy create the basis for the search for new tools and technologies in the field of promoting territories in the interregional market of tourist services. At the heart of formation of the concept of promoting the territory in the market of tourist services lies the effective use of its tourist potential and formation of inter-organizational relations in the tourist-recreational network of the territory, which contributes to an increase in the attractiveness of a city, a region on the inter-regional market of tourist services. When forming the concept of promoting domestic regions in the interregional tourism services market, in addition to the consequences of the pandemic, it is necessary to take into account the current long-term trends: insufficient popularization of domestic territories in the tourism services market. The unsatisfactory quality of tourist services provided is confirmed by the contribution of tourism to the gross domestic product of the Russian Federation, which amounted to only $5.0 \%$ in 2019 , with an average global value of this indicator of $10.2 \%$.
\end{abstract}

Keywords: pandemic, promotion concept, region, territory, touristic services, regional marketing, tourism, touristic destination.

\section{INTRODUCTION}

Todate branding of the region has become a procedure of conscious and targeted development of the brand of the region, namely the selection, display and formation of the identity of the region, as well as its promotion in bright, related images attractive to the target audience[1]. Geobrending is a mechanism that enables marketing to be pragmatic for categories such as location (territory)[2]. Two main stages are included in the marketing of the region - the positioning of the region and promotion.

In the context of branding, the positioning stage of the region implies the search for the identity of the region, competitive advantages, the development of a new (or lost) the meaning of the place, the intentions of the inhabitants[3]. The period of formation of the brand concept is attributed to the positioning stage[4]. The implementation and embodiment of brand ideas in the regional environment and in the information space is timed to the stage of promotion of the region[5].

From the information given in Table 1, it can be said that in the Russian Federation, as well as in other countries of the world, the development of the tourism industry with a focus primarily on the domestic consumer strongly depends on the success of the fight against the pandemic. 
Table 1. The main indicators of the development of the tourism industry in the Russian Federation in the 1st quarter of 2020

\begin{tabular}{|c|c|c|c|c|}
\hline Indicators & $\begin{array}{l}\text { I quarter } 2020 \\
\text { г. }\end{array}$ & $\begin{array}{l}\text { II quarter } \\
2020 \text { г. }\end{array}$ & $\begin{array}{l}\text { Growth I quarter } \\
2020 \text { by the first } \\
\text { quarter } 2019 \text {, in } \\
\%\end{array}$ & $\begin{array}{l}\text { Growth II } \\
\text { quarter } 2020 \text { by } \\
\text { the second } \\
\text { quarter } 2019 \text {, in } \\
\%\end{array}$ \\
\hline $\begin{array}{l}\text { Number of persons placed in collective } \\
\text { accommodation facilities, thousand people }\end{array}$ & 12714,9 & 2094,9 & $-2,2$ & $-87,9$ \\
\hline including: Russian citizens & 11353,4 & 1955,9 & 1,0 & $-86,7$ \\
\hline foreign citizens & 1361,5 & 139,0 & $-22,6$ & $-94,7$ \\
\hline Number of inbound tourist trips, thousand & 3798,2 & 66,5 & $-11,2$ & $-99,0$ \\
\hline $\begin{array}{l}\text { Number of outbound tourist trips, } \\
\text { thousand }\end{array}$ & 7002,2 & 116,1 & $-9,8$ & $-99,0$ \\
\hline Passenger turnover, billion passenger.km & 111,2 & 30,3 & $-4,7$ & $-78,8$ \\
\hline of these, by type of transport: railway & 24,4 & 9,5 & $-2,1$ & $-71,4$ \\
\hline air (transport aviation) $)^{1)}$ & 61,2 & 9,0 & $-5,6$ & $-88,9$ \\
\hline $\begin{array}{l}\text { The scope of services of travel agencies, } \\
\text { tour operators and other services on } \\
\text { booking and related services, billion rubles. }\end{array}$ & 32,8 & 2,9 & 2,9 & $-93,4$ \\
\hline $\begin{array}{l}\text { The volume of services of sanatorium- } \\
\text { resort organizations, billion rubles. }\end{array}$ & 21,5 & 2,3 & $-1,1$ & $-92,6$ \\
\hline $\begin{array}{l}\text { The volume of services of hotels and similar } \\
\text { services for the provision of temporary } \\
\text { housing, billion rubles. }\end{array}$ & 50,1 & 10,1 & $-3,0$ & $-83,7$ \\
\hline $\begin{array}{l}\text { Export of services under the article } \\
\text { "Trips"2), } \\
\text { billion US dollars }\end{array}$ & 1721,9 & 138,0 & $-9,2$ & $-95,2$ \\
\hline as \% of total exports of services & 12,8 & 1,8 & - & - \\
\hline
\end{tabular}

1) According to the Federal Air Transport Agency.

2) According to the balance of payments of the Bank of Russia (estimate of the second quarter of 2020).

\section{STYLE PALETTE}

A well-known branding technology is the formation of a calendar of events aimed at promoting the territory. All events on a scale can be divided into: mega events (Olympic Games, EXPO), medium-scale events and micro-events. The scale of the event depends not only on the number of participants (in the sum of tourists and locals), but also on the amount of financial resources needed for its organization, the amount of income received, as well as on the proportion between the number of visitors and locals. It is mega-events that are the most attractive, since they allow the territory to declare itself on an interregional scale, and although their organization and holding require huge resources, the return in most cases justifies these investments.

As a rule, there are two types of events: commercial events, which are generally profit-oriented, noncommercial, aimed at achieving a social effect, popularizing cultural traditions, organizing leisure activities for residents and guests (state and national holidays, city days, cultural events).

All three scenarios of the dynamics of international tourist flows cited by the International Tourism Organization are more than pessimistic - a decline in the number of trips by $58-78 \%$ in 2020 . On the other hand, the Russian Federation, in case of a successful fight against the epidemic, has a chance to mitigate losses by reorienting outgoing tourist flows to the domestic market and even expand them.

An important direction in the formation of territorial branding is to work with the population - through the media and the use of participatory practices participatory tools) - various technologies for involving the population in decision-making, social design technologies, competitive mechanisms, crowdsourcing and crowdfunding. Such technologies are widely used in traditional marketing, but their application in the marketing of territories is especially promising, since the population is the main stakeholder in this process. A large-scale project is the portal "Our City": "a unique project designed to improve the quality of life of citizens and the appearance of Moscow through the active participation of Muscovites in the life of the capital"[7].

It is necessary to focus on digital technologies for the promotion of territories. Digital technologies in this case means not only the use of the Internet, but also mobile phones, tablets and other means of electronic communication, on-screen advertising. All aspects are important: the quality of information on the official website of the territory, the representation of the territory in various social networks, reviews of the territory on the Internet, the availability of various 
mobile applications about the territory, etc. Many Russian cities are provided with 3D virtual tours and 3D maps.

A wide variety of governmental, commercial and non-profit structures, including chambers of commerce and industry, public organizations (associations of marketers, tourism associations, associations of hoteliers and restaurateurs, etc.), tourism development centers, corporations and territorial and investment development agencies, etc., can develop marketing strategies and perform marketing functions. Congress bureaus are common practice for international and now for Russian reality to implement marketing functions on the territory [8].

\section{MATH AND EQUATIONS}

Scalar variables Anti-crisis strategies of territorial development in general, as well as concepts of territory promotion, are largely based on tourist potential.

Tourism plays an increasingly important role in economic development and, accordingly, becomes one of the most important foundations for the formation of the image and brands of territories[6]. There are several types of strategies for the formation of the tourist component of the economy.

Taking into account the specifics of a certain target audience and its needs, it is possible to form a product specific to this audience[7].

In the case of a successful fight against the epidemic, there is a chance to mitigate losses by reorienting outgoing tourist flows to the domestic market and even expand them.

Network interaction is one of the important conditions for the effective functioning of the tourist and recreational sphere, and its study in the managerial aspect is becoming an urgent research area. From the perspective of the named vector of scientific search, the effectiveness of IOR deserves special attention. Both the content of the IOR effectiveness category and its evaluation are in the initial stage of discussion.

Interorganizational relations (in foreign sources, the abbreviation - IOR (interorganizational relationships) is common), represented by such forms of interaction as association, alliance and cooperation, provide their participants with certain benefits: sharing resources, staff training, knowledge sharing, reducing costs for marketing and PR activities, performing managerial functions. Effective IORS ensure the achievement of common strategic goals, quantitative and/or qualitative synergetic effects in the field of tourist and recreational services of certain territories, such as, for example, employment of the local population, sustainable competitive advantage of the territory (tourist destination), solving environmental problems, sustainable development. Thus, the evaluation of the effectiveness of interorganizational interaction in the tourist and recreational network should be carried out in the two aforementioned perspectives, which, from our point of view, will allow us to deepen the understanding of the category under study, to conclude not only about the level of effectiveness of interorganizational interaction, but also about its nature, for example, partially opportunistic or, on the contrary, mutually beneficial relations between partners.

Indicators characterizing the functions of relations can be used by the management of the companies belonging to the alliance to identify problems of interaction, set goals for inter-organizational relations and determine the degree of their achievement.

\section{FIGURES AND TABLES}

The conducted research of theoretical and methodological aspects of the promotion of territories to the world market of tourist services, the analysis of the main trends in the development of the world market of tourist services, allowed us to conclude that in the conditions of pandenomics, the promotion of tourist resources of the territory is no less important than the increase in economic and social potential[9]. In fact, these processes should go in parallel, and the potential of the territory should correspond to its image, and a positive image should focus on the effective use of the accumulated potential.

Territories are becoming extremely inventive in using traditional marketing technologies for their branding and promotion, however, promotion to the

Table 2. Types of strategies for the formation of the tourist component of the economy

\begin{tabular}{|l|l|l|}
\hline Type & Characteristic & Examples \\
\hline $\begin{array}{l}\text { The } \\
\text { first }\end{array}$ & $\begin{array}{l}\text { commercialization of accumulated cultural and } \\
\text { recreational heritage (architectural, literary, } \\
\text { artistic, etc.). }\end{array}$ & $\begin{array}{l}\text { formation of a link between the genius of the place and } \\
\text { the territory (G.Polevskoy- P.Bazhov) }\end{array}$ \\
\hline Second & $\begin{array}{l}\text { transformation of former industrial facilities into } \\
\text { cultural clusters }\end{array}$ & $\begin{array}{l}\text { Yekaterinburg - (Ural Industrial Biennale of } \\
\text { Contemporary Art, Sysert - project "Summer at the } \\
\text { factory", Moscow - art cluster "Red October" }\end{array}$ \\
\hline Third & $\begin{array}{l}\text { creation of "virtual" objects of tourism and } \\
\text { culture, or mobile projects that are easily } \\
\text { transferred from place to place }\end{array}$ & Vienna Music Film Festival in Yekaterinburg. \\
\hline
\end{tabular}


world market of tourist services is not a simple tracing paper from promotion within the country[10]. From the authors' point of view, this is a more complex and multifaceted process that requires the involvement of all significant factors and stakeholders of the territory.

As a result of the analysis of the state and trends in the development of the interregional tourism services market, a number of technologies, tools and organizational structures for promoting territories in the interregional tourism services market are presented, taking into account the specifics of the activities of its subjects in the conditions of a pandemic and the effectiveness of the use of tourist potential[11]. In general, the results obtained allow us to state the following:

1. In the long term, the effectiveness of interorganizational relations in the model increases there is a pronounced positive dynamics of the general and average degree of satisfaction, as well as the average degree of mutual satisfaction of agents.

2. The collaboration of stakeholders leads to a partial loss of the power of influence of its individual participants, but these losses are compensated by the benefits obtained as a result of increasing the effectiveness of inter-organizational interaction.

3. Cooperation brings certain benefits to stakeholders, determined by indicators of the effectiveness of inter-organizational interaction. The dynamics of changes in some performance indicators (including monetary ones) affects the perception of certain non-monetary characteristics of the quality of relations (stability, fairness).

\section{REFERENCES}

[1] Whang, Haesung, Yong, Sunghwa, Ko, Eunju, Pop culture, destination images, and visit intentions: Theory and research on travel motivations of Chinese and Russian tourists in: Journal of Business Research (2005).

[2] S. Zenker, E. Braun, S. Petersen, Branding the destination versus the place, The effects of brand complexity and identification for residents and visitors in: Tourism Management, 58 (2017) pp. 1527.

[3] Local Burden of Disease, H.I.V.C. 2021 Local Burden of Disease, H.I.V.C.

[4] Mapping subnational HIV mortality in six Latin American countries with incomplete vital registration systems BMC Med., 19(1) (2021) p. 4.

[5] E.Y. Unkurov, Branding of territories: foreign and domestic experience in: Bulletin of IKIAT, 2(41) (2020). https://cyberleninka.ru/article/n/brendingterritoriy-zarubezhnyy-i-otechestvennyy-opyt.
[6] N. NeJhaddadgar, et al. Effectiveness of telephonebased screening and triage during COVID-19 outbreak in the promoted primary healthcare system: a case study in Ardabil province, Iran Z Gesundh Wiss (2020) pp. 1-6.

[7] S. Kallbekken, H. Sælen, Public support for air travel restrictions to address COVID-19 or climate change in: Transp. Res. Part D, 93 (2021) 102767.

[8] G. Aliperti, et al. Tourism, crisis, disaster: an interdisciplinary approach in: Ann. Tour. Res., 79 (2019) 102808.

[9] Y. Li, et al. Seeking and sharing health information on social media: a net valence model and crosscultural comparison in: Technol. Forecast. Soc. Change, 126 (2018) pp. 28-40.

[10]Local Burden of Disease, H.I.V.C. 2021 Local Burden of Disease, H.I.V.C.

[11] S. Bensalem, M. Bogza, A. Legay, T.H. Nguyen, J. Sifakis, R. Yan, Incremental component-based construction and verification using invariants, in: Proceedings of the Conference on Formal Methods in Computer Aided Design (FMCAD) in: IEEE Press, Piscataway, NJ (2010) pp. 257-256.

[12]H. Barringer, C.S. Pasareanu, D. Giannakopolou, Proof rules for automated compositional verification through learning in: Proc. of the 2nd International Workshop on Specification and Verification of Component Based Systems (2003).

[13]M.G. Bobaru, C.S. Pasareanu, D. Giannakopoulou, Automated assume-guarantee reasoning by abstraction refinement in: A. Gupta, S. Malik (Eds.), Proceedings of the Computer Aided Verification, Springer, Berlin, Heidelberg (2008) pp. 135-148. DOI: https://doi.org/10.1007/978-3540-70545-1_14. 